\title{
On Sortition. Comment on "Proposals for a Democracy of the Future" by Bruno Frey
}

\author{
George Tridimas ${ }^{1}$
}

Received: 1 May 2017/ Accepted: 15 July 2017/Published online: 3 November 2017

(C) The Author(s) 2017. This article is an open access publication

\begin{abstract}
Among the several thought provoking arguments for reforming democracy, Bruno Frey advocates sortition, that is, appointment to (some) public offices by lottery. Sortition was the hallmark of the direct democracy of ancient Athens. The paper assesses the Athenian practice of sortition by the criteria of representativeness, equity, partisanship, rent seeking, resource economy, and suitability of candidates for office. It concludes that, in view of fundamental conceptual differences between the Athenian democracy and the modern representative government, introduction of sortition into modern representative democracy poses extremely demanding challenges.
\end{abstract}

Keywords Sortition - Ancient Athens - Direct democracy · Representative democracy

JEL Classification D7 · N4

\section{Introduction}

In his thought-provoking essay, Bruno Frey (2018) proposes a range of far-reaching reforms of representative democracy to introduce more direct participation in public decision making. ${ }^{1}$ This essay focuses on proposals to introduce random selection. Specifically, Frey proposes to decide the outcome of referendums by lot where the probability that each alternative wins depends on the share of votes polled, and to use

\footnotetext{
1 Frey is not alone in arguing that elections are not synonymous with democracy; see, for example, Van Reybrouck (2016).

George Tridimas

G.Tridimas@ulster.ac.uk

1 Department of Accounting, Finance and Economics, Ulster Business School, Shore Road, Newtownabbey BT37 0QB, UK
} 
sortition (drawing lots among citizens) to fill some public offices. Proposals to replace majority voting with random selection raise questions about the nature of democracy, representation of voters and selection of government officials. The proposal for randomising policy has been made in the literature but has not been applied in practice. Mueller et al. (1972) favour randomized selection of legislators for reducing incentives for pork barrel activities, achieving ex ante equality of voters, representing minorities proportionately and avoiding intransitive voting outcomes. Amar (1984) discusses the benefits of choosing representatives under lottery voting, a system where citizens vote for representatives (as per usual practice), but the election winner is decided by a lottery of the ballots cast, so that a candidate who polls say $\mathrm{x} \%$ of the vote has $\mathrm{x} \%$ ex ante probability to be elected to office, rather than $100 \%$.

The proposal for sortition of public post-holders has a long and distinguished pedigree in the direct democracy of ancient Athens (507-322 BCE), Venice (697-1797), Florence (1328-1434 and again 1494-1512) and the Swiss Landsgemeinden (1640-1837). This comment discusses the sortition proposal using the intuition gained from the scholarship developed in relation to ancient Athens and arrives at a more nuanced conclusion than Frey's optimism.

In the modern eyes, sortition denies the exercise of choice according to the preferences of the voters and is "a-rational" (Dowlen 2008) as it implies a fixed probability of winning independent of personal effort and other characteristics of those contesting the election. As such, it goes against the grain of a number of well-accepted and reasonable arguments for electing candidates to office. Most importantly, the principle of one-person one-vote to elect government officials offers each citizen an equal opportunity to consent to the government. The policy decisions made by the elected officials, and especially the constraints they impose on individual actions, are then perceived as legitimate. Further, voting in a fair election makes possible to discover the individuals who possess merit and ability to occupy public office and conduct policy, and the outcome of voting embodies the wishes of the majority. If these are true, sortition not only changes the nature of modern democracy but also carries the risk of appointing unqualified candidates to office. ${ }^{2}$

Section 2 reviews the ancient Athenian practice of selection to office by lot, the institutional setting and circumstances where it was used. Section 3 uses the criteria of representativeness, equity, partisanship, rent seeking, resource economy and suitability for office to evaluate the Athenian arrangement, and contrasts it with the premises of modern democracy. Section 4 concludes.

\section{Sortition in the Direct Democracy of Ancient Athens ${ }^{3}$}

Representative democracy is diametrically different from the direct democracy of ancient Athens where policy was debated and then voted by the Assembly of citizens and a large number of public offices where filled by lot drawn among the

\footnotetext{
${ }^{2}$ Note, however, that the problem of unqualified office-holders does not arise under lottery voting, because the electorate, similarly to standard elections for office, still chooses the candidates it prefers.

3 Tridimas (2011) and Lyttkens (2013) offer wide-ranging examinations of the institutions of the Athenian democracy in the light of political economy.
} 
eligible citizens volunteering for service. Elements of direct democracy survive today in the form of the referendum, where citizens are asked to approve or reject a particular policy motion. Random selection to office by lot has also survived in appointing court juries, but is unheard of in the case of filling government posts. Along with policy making by the Assembly of the demos, the hallmark of the Athenian democracy was appointment to public office by lot. During the 4th century the lot was used to appoint annually approximately 7000 public post-holders out of an estimated population of 20,000 eligible (male) citizens above the age of 30 years, the minimum age for holding office. Three types of officers were appointed by lot, namely, the members of the Council of the Five Hundred, six hundred magistrates responsible for various duties delegated by the Assembly, and six thousand members of the popular Court. Councillors, jurors of the Court and members of (some) boards received a fee for their days of service. The payment was necessary for otherwise citizens, especially the poorer, could not take the time off their farms and trades to serve in public office.

The Council of the Five Hundred ("Boule") had wide administrative powers but no decision making authority. It received foreign dignitaries, could investigate other officers, prepared the agenda for the Assembly, monitored public finances (without authority to levy taxes or spend public money), and was responsible for the day-today administration of the state. "It was concerned not with policy but with business" (Headlam, p. 57) and "while it performed the duties of preparing and arranging business, it did not put any check on the complete freedom of discussion of the Assembly" (ibid, p. 63). The Council met at least 250 days a year in sessions open to the public and its members received the mean wage as compensation for their services.

Numerous boards, typically ten-member strong, were appointed every year to execute and administer a variety of functions as voted by the Assembly producing a total of approximately six hundred magistrates. Their functions included religious affairs, inspections of markets, private and public buildings, roads and water supplies, preparation of trials and chairmanship of courts. Prominent amongst the boards was the board of the nine archons. In Archaic Athens (750-500), the latter were the highest state officials with religious, military, administrative and judiciary responsibilities and were selected from the aristocratic class of wealthy landowners only. ${ }^{4}$ Amongst other important boards of officials described in the sources were the public accountants of the state; the receivers of the public revenues; the spending officers; the sellers of public property whose responsibilities also included public tenders for public works; those responsible for confiscation, prisons and executions; and the inspectors of the dockyards and the corn-wardens.

The popular Court (known as Heliaia) conducted civil, penal and political trials. The latter accounted for the largest part of its workload and were divided as follows: (1) A triple scrutiny of the citizens occupying public office (a) checking the eligibility, reputation and conduct of candidates before taking office, but not ability

\footnotetext{
${ }^{4}$ After serving their terms archons became life members of the Council of Areopagus, which in the archaic times enjoyed considerable powers, overseeing laws, other magistrates, and conducting trials. However, with the establishment of democracy its powers were transferred to the Assembly, the Council and the Court and in 462 it was reduced to a court for homicides.
} 
or competence; (b) ruling on allegations for misconduct during service; and (c) reviewing service after completing his office term, especially if they were administering public funds. (2) Indictments for illegal proceedings and applications for annulment, that is, checks of the validity of the decisions of the Assembly ("graphe paranomon"), where the court had the power to annul a decree and punish its proposer. (3) Impeachments, that is, trials of the elected generals for the crimes of attempting to overthrow the constitution, treason or corruption after the Assembly had referred such a case to the Court ("eisangelia"). The Court met about 200 days a year. Each Court day, about 2000 out of the 6000 members were selected by lot to serve as jurors; following a further lot they were then allocated to the various cases tried on the day. ${ }^{5}$ Court rulings were decided by majority voting in secret ballots among the members of the jury. Headlam (1891) attributes the almost incessant use of the Court to charge one's political opponents to sortition arguing that when elections lack partisanship, accusation and condemnation in the Court become the means for hurting political opponents.

After the Athenian defeat in the Peloponnesian War in 404, and upon blaming the demagogues for misleading the demos, the power to make laws ("nomos") describing "general norms without limit of duration" was taken away from the Assembly and given to a special board of legislators, chosen by lot from the same panel of 6000 jurors of the People's Court. The Assembly kept its rights to pass decrees ("psephisma"), decide foreign policy, and elect magistrates. Assembly decrees had to be in accordance with the laws. Passing laws proceeded like a trial. The author of the proposed law put the case to the board of legislators; five advocates would speak against the law and the legislators would then vote by show of hands. The Court was granted the power to nullify Assembly measures deemed contrary to the laws, fine their proposers, and impeach politicians accused for attempting to overthrow the constitution, treason, deceiving the people and corruption. This implies that the Athenians developed an early form of judicial review of policy. Effectively a judicial collective body consisting of members appointed by lot became a veto player. ${ }^{6}$

The sortitioned public post-holders served annual terms implying that considerable rotation took place. Service in the Council of Five Hundred was restricted to two terms over the lifetime, but not in consecutive years, and once in other magistracies, although there was no limit on the number of times one could be elected general. Court jurors too were re-eligible. Hansen (1999) calculates that in the 4th century two-thirds of the eligible citizens served at least once as members of the Council (p. 249 and p. 313). A man could hold different magistracies after his term in one office had expired and reviewed by the Court, which effectively meant that he could potentially serve in different offices every other year. Citizens had the

\footnotetext{
5 In Aristotle (1984), Rhodes describes the allotment machines operated with bronze and wooden tickets, relying on simple yet ingenious mechanisms to prevent cheating. Rhodes (1986) argues that the elaborate system of allotting juries ensured not only that no one could predict which jurors would try which case but also that the same men would not sit together on the same panel day after day.

6 In this connection, Hansen (2010, pp. 525-526) advances the argument, not necessarily accepted by all ancient historians, that in the 4th century the Court was in control of politics rather than the Assembly.
} 
right but not the obligation to serve in office and post-holders were appointed from those who were willing to serve.

Historians disagree on the exact date appointment by lot was introduced as the extant sources are not very clear. Even though its origin seems to be religious, in that the lot outcome reveals the choice of gods, the Athenians did not attribute any religious significance to sortition outcomes (Headlam 1891). The Council of the Five Hundred was probably filled by lot from the start of the democracy. Lot was certainly used in selecting the nine archons in 487/6. Lyttkens (2013) explains the introduction of sortition to select the archons as a form of self-regulation introduced by the aristocracy that ruled Athens in the archaic times. He argues that its purpose was to reduce intra-elite competition for power because such competition was costly and undermined the ability of the elite to rule. More formally, in a model where a citizen divides his time between private work and work from public office, Tridimas (2012) shows that a contestant for office prefers to be subject to the luck of the draw instead of fighting for it in an election, when the probability of winning the election is less than the probability of winning the lot by a factor that accounts for the cost of election campaign net of the intrinsic utility from public office. However, use of random selection to office demonstrated that no special abilities or skills were necessary to hold such office. Thus, sortition inevitably diminished the status of the offices of archons and opened them up to all citizen classes, significantly, poorer members of the demos. The members of the Council, other magistrates and jurors of the Court were soon drawn from ordinary citizens. As such, they were amateurs lacking formal training rather than professional politicians or administrators with expertise.

Not all sortitioned posts were equally regarded; some, like those of archons, were highly prestigious while others less so but carried perks. The posts were filled by volunteers, no citizens was coerced to take up public office. This raised the problem of whether enough volunteers would be forthcoming. Motivating citizens by democratic ideology and notions of civic duty may ameliorate but not eliminate the problem, while paying them a fee for service may better appeal to financial incentives. It turns out that by and large lack of volunteers to serve was not a problem (Hansen 1999). Using a formal model, where appointment to office takes place through election or sortition is decided at the constitutional stage, Tridimas (2012) shows that poor Athenians with few means to support themselves but their own work, and with labour productivity less than the mean wage, were better off by being included in the pool of candidates for public office, where if selected received the relevant fee for service. It then follows that whatever their ethical motivations, participating in government was fully consistent with selfish financial motives of utility maximization and offers a formal economic explanation of why the ancient Athenian democracy was highly participatory. Further, other things being equal, a citizen will be interested in seeking office through election only if office won through election confers higher intrinsic value than appointment to office through sortition. 


\section{Properties of sortition and their applicability to Athens}

\subsection{Representativeness}

A random selection of a large sample from the entire population produces a set of individuals that reflects accurately the composition of the population with respect to personal characteristics, political preferences and economic circumstances. As a result, the decision of the sample will be perceived as standing for the population as a whole. Nevertheless, for the Athenians, who understood intuitively that the lot picked representative samples of the population, representativeness was an incidental corollary of sortition, since their democracy was a direct one.

\subsection{Equity}

Sortition satisfies the criterion of horizontal equity, in the sense that when there are no good reasons to favour one candidate for office over another, sortition gives them equal chances of success. Stone (2009) describes it as "the sanitizing effect of the lottery"; it offers a strong argument to use the lottery when it is feared that a decision will be made for a bad reason. Sortition in Athens offered all citizens equal opportunities to hold public office which in turn implied equal opportunities to obtain the rents from public office. In sharp contrast, equality of opportunity to occupy office did not feature in the struggle for suffrage extension in building modern democracies, where parties and candidates have unequal chances of being elected to office. Several reasons account for the latter inequality. First, voters may treat different candidates differently. Second, each candidate for office tries to distinguish himself from the rest to emphasize what makes him different from the rest in order to stress his superiority and show his suitability for office. Thus, two candidates adopting equal policy positions have unequal probabilities of winning because valence also affects voters' judgments. Finally, candidates with unequal resources at their disposal hold unequal electoral advantages. In view of these inequalities elections for representatives produce office holders with characteristics that are different, perhaps "superior" to those of voters. ${ }^{7}$ On account of these considerations, an ancient Athenian might have rejected modern representative government as an elective oligarchy. Further, appointment by lot meant that any citizen might hold office, while with rotation every citizen might hold office at some point (Engelstad 1989). Randomly selected officers who owe their positions to the luck of the draw, and appreciate that in turn they will be "ruled" by those they now rule, cannot be thought as a ruling elite or an exclusive body. Hence, they can make only moderate demands on fellow citizens lessening government coercion.

\footnotetext{
${ }^{7}$ As Manin 1997, p. 147, astutely observes "It is no accident that that the terms 'election' and 'elite' have the same etymology."
} 


\subsection{Partisanship}

Elections in modern representative democracies are contests between political parties. On the contrary, there were no political parties in Athens. Elections were mainly contest about the suitability of a person to perform specific tasks, like those of a general, rather than class or ideology. As policy was decided by the Assembly, public post-holders were not equivalent to modern secretaries of state. In modern democracies elections are important because the voters cannot exercise direct control over the actions of the government during the period between elections, and the government officials enjoy significant independence of action. On the contrary, in Athens the citizens-voters always controlled the state directly, and magistrates, elected or allotted by sortition, lacked independence. ${ }^{8}$ Moreover, sortition and rotation resulted in a very large number of ordinary citizens obtaining on-hand experience of what was going on in the affairs of the state. This resulted in a highly informed citizenry familiar with the affairs and administration of the state. Further, dispensing justice by large juries of untrained amateurs selected randomly implied that (in contrast to Roman law) laws remained short, simple and straightforward, did not need authoritative interpretation; nor could court rulings create a legal precedent. In addition, since the outcome of the lot was unpredictable no political group could plan to place its supporters in positions of power or systematically advance its interests by occupying office. As a corollary, the ability of the elite to exert patronage was weak and no particular faction could entrench itself in office.

\subsection{Rent seeking}

Government policies create distributional gains and economic rents which in turn generate incentives for rational actors to spend resources seeking those rents instead of creating new wealth. No polity is free of such rent seeking activities. Sortition mitigates rent seeking significantly because random allocation of rents diminishes the benefits from running campaigns to win over voters and lobbying politicians to influence government policy. ${ }^{9}$ In addition, given the transparency of the system (in view of the judicial monitoring described above), sortition decreases corruption because randomly selected and frequently alternating officers cannot be bribed in advance.

\subsection{Resource cost of collective choice mechanism}

Sortition is cheaper to organise and run than elections. Minimisation of such resource costs may not be the most pressing consideration when choosing officials but cannot be ignored either.

\footnotetext{
8 These observations may well explain the small number of reference to elections by the ancient authors, and the complete absence of today's ubiquitous office of Prime Minister.

9 See Tridimas (2015) for a detailed examination of rent creation, rent seeking behaviour and mechanisms to control the latter in ancient Athens.
} 


\subsection{Candidate suitability for office}

As already noted sortition carries the risk of appointing unsuitable and unqualified candidates to office with detrimental effects for citizen welfare. Indeed, this argument was advanced by no less authority than Socrates, who pointed to "the folly of appointing public officials by lot, when none would choose a pilot or builder or flautist by lot, nor any other craftsman for work in which mistakes are far less disastrous than mistakes in statecraft" (Xenophon, Memorabilia 1.2.9). Two important points in defence of the Athenian use of the lot can be made here. First, the Athenians did not randomly assign men to posts requiring ability or knowledge and expertise in the discharge of duties. For such posts they used elections, as for example, for the position of general, where the citizenry could select those that they trusted to lead them to battle. Second, only posts for public administration tasks that could be carried out by ordinary men without special talents or expertise were filled by sortition. Formally (see Tridimas 2012), a citizen who wishes to appoint a candidate to public office incurs a certain cost of making an informed choice, while he derives an uncertain benefit from the actions of the appointed official (because the official actions may confer a gain to the citizen or inflict a loss to the citizen). When the marginal benefit from the extra effort to think and select between different candidates for office is small in comparison to the cost of that effort, either because the uncertain extra gain is small or the cost of time given up to make an informed choice is large, the citizen is better off by giving up such choice and allocating public offices randomly across those interested in serving.

Council members, court jurors and the other magistrates were all citizens without special training for the task undertaken. To put it another way, the Athenians accepted that the acts of boards filled by sortitioned members were invariant to the composition of those boards. ${ }^{10}$ With board members selected by lot, Athens did not develop classes of professional politicians, lawyers, or officials to man a permanent state bureaucracy. ${ }^{11}$ Citizens in public posts carried out administrative tasks designed for non specialists "with reasonable intelligence and motivation" (Hansen, 1999, p.244). ${ }^{12}$ This way, the supremacy of the demos in the Assembly or the Court could not be challenged.

\section{Conclusion: Why Sortition may not Work}

To the modern eye, competitive elections under universal suffrage is so established that appointment to public office by lot may feel as incongruous as letting the minority rule over the majority. Yet, Frey argues that in so far as democracy is not

\footnotetext{
10 According to Rajagopalan and Wagner (2013), the invariance property is a requisite of the rule of law, in the sense that the law is independent of the men who articulate it (for otherwise it reduces to the rule of men).

11 The latter is also related to the light tax treatment of the vast majority of Athenians, for more details see Tridimas (2015).

12 Such post-holders were nevertheless helped by a small number of secretaries who rotated from one task to another as they were not allowed to serve the same magistracy in the same capacity twice.
} 
tantamount with elections random selection may improve democratic outcomes. Ancient Athens is a case in point, as sortition was integral to democracy. Using what is known about the Athenian direct democracy and the insights of public choice theory, the present comment made three points. First, the Athenians did not randomise policy, but deliberated and voted for against proposals in the Assembly of the Demos. Second, the Athenian democracy was predicated on citizens having an equal right to hold public office irrespective of birth, wealth or any other characteristic. It is for this reason that sortition for public office to carry out routine tasks was accepted. On the contrary, modern democracy is predicated on citizens having equal rights to consent to the government that rules them. Finally, as the essence of the Athenian democracy was that the demos should rule, appointed officials lacked independence of action and carried out administrative duties; similarly, magistrates with judicial responsibilities administered proceedings and decided the cases in front of them but did not interpret the law.

Clearly, the Athenian democracy was fundamentally different from the present representative democracy. Assembly deliberation, the rule of simple majority, absence of political parties, citizen participation through the courts, and sortition were a joint constitutional package, inexorably linked and mutually reinforcing. Therefore, an institution like sortition that served the direct democracy well may not be easily transferable to a representative democracy without the rest of the institutional structures. Cutting and pasting sortition from Athens to today is not the same thing as grafting it to the current institutional structure, and may fail to deliver "a better democracy". Be that as it may, like all proposals for institutional reforms, whether introduction of random selection will be undertaken depends on whether the constitutional framers expect to benefit from it. This, however, is an issue for a different research project.

Acknowledgements I would like to thank Manfred Holler for his encouragement and input in preparing this essay. He is not responsible for any remaining errors and omissions.

Open Access This article is distributed under the terms of the Creative Commons Attribution 4.0 International License (http://creativecommons.org/licenses/by/4.0/), which permits unrestricted use, distribution, and reproduction in any medium, provided you give appropriate credit to the original author(s) and the source, provide a link to the Creative Commons license, and indicate if changes were made.

\section{References}

Amar, A. R. (1984). Choosing representatives by lottery voting. Yale Law Journal, 93, 1283-1308. Aristotle (1984) The Athenian constitution. London: Penguin Classics. (Translated by P.J. Rhodes) Dowlen, O. (2008). The potential of sortition. A study of the random selection of citizens for public office. Exeter: Imprint Academic.

Engelstad, F. (1989). The assignment of political office by lot. Social Science Information, 28, $23-50$. Frey, B. S. (2018) Proposals for a democracy of the future. Homo Oeconomicus, 35, (forthcoming) Hansen, M. H. (1999). The Athenian Democracy in the Age of Demosthenes. Structure, Principles and Ideology. London: Bristol Classical Press. 
Hansen, M. H. (2010). The concepts of demos, ekklesia, and dikasterion in classical Athens. Greek, Roman, and Byzantine Studies, 50, 499-536.

Headlam, J. W. (1891). Election by lot in Athens. Cambridge: Cambridge University Press.

Lyttkens, C. H. (2013). Economic analysis of institutional change in ancient Greece Politics, taxation and rational behaviour. Abingdon: Routledge.

Manin, B. (1997). The principles of representative government. Cambridge: Cambridge University Press.

Mueller, D. C., Tollison, R. D., \& Willet, T. D. (1972). Representative democracy via random selection. Public Choice, 12, 57-69.

Rajagopalan, S., \& Wagner, R. E. (2013). Constitutional craftsmanship and the rule of law. Constitutional Political Economy, 24, 295-309.

Rhodes, P. J. (1986). Political activity in classical Athens. The Journal of Hellenic Studies, 106, 132-144.

Stone, P. (2009). The logic of random selection. Political Theory, 37, 375-397.

Tridimas, G. (2011). A political economy perspective of direct democracy in ancient Athens. Constitutional Political Economy, 22, 58-72.

Tridimas, G. (2012). Constitutional choice in ancient Athens: the rationality of selection to office by lot. Constitutional Political Economy, 23, 1-21.

Tridimas, G. (2015). Rent seeking in the democracy of ancient Greece. In A. L. Hillman \& R. D. Congleton (Eds.), The Elgar companion to the political economy of rent seeking (pp. 444-469). Cheltenham: Edward Elgar Publishing.

Van Reybrouck, D. (2016). Against elections: The case for democracy. New York: Random House. 